\title{
Valorization of Orange Peel Waste Using Precomposting and Vermicomposting Processes
}

\author{
Lorena De Medina-Salas ${ }^{1, *}$, Mario Rafael Giraldi-Díaz ${ }^{1}$, Eduardo Castillo-González ${ }^{2}$ \\ and Laura Elena Morales-Mendoza ${ }^{1}$ \\ 1 Facultad de Ciencias Químicas, Universidad Veracruzana, Circuito Gonzalo Aguirre Beltrán, \\ Zona Universitaria, Xalapa 91040, Veracruz, Mexico; mgiraldi@uv.mx (M.R.G.-D.); \\ zS19026545@estudiantes.uv.mx (L.E.M.-M.) \\ 2 Facultad de Ingeniería Civil, Universidad Veracruzana, Circuito Gonzalo Aguirre Beltrán, \\ Zona Universitaria, Xalapa 91040, Veracruz, Mexico; educastillo@uv.mx \\ * Correspondence: ldemedina@uv.mx; Tel.: +52-228-8421758
}

Received: 13 August 2020; Accepted: 10 September 2020; Published: 16 September 2020

\begin{abstract}
The industrialization process of oranges generates waste, which is inadequately disposed of; this produces adverse effects on the environment. Among the alternatives for valorization is the vermicomposting process, which consists of the degradation of organic waste through the action of earthworms and microorganisms. Therefore, this research aimed to study this process using orange peel (OP) waste at the laboratory level. For this purpose, it was necessary to determine the degradation conditions through the monitoring of physicochemical parameters (temperature, $\mathrm{pH}$, humidity, organic matter (OM), total organic carbon (TOC), total nitrogen (TN) and the carbon/nitrogen $(\mathrm{C} / \mathrm{N})$ ratio). To balance the substrate's nutrients, load material (LM) that included vegetable waste and eggshells was added to three different mixtures: M1 (50\% OP + 50\% LM), M2 (40\% OP + 60\% $\mathrm{LM})$ and M3 (60\% OP $+40 \% \mathrm{LM})$. To condition the substrate for earthworm (Eisenia fetida) activity, a previous precomposting process was performed. The results showed that all the mixtures fulfilled the requirements for a quality and mature vermicompost; however, the highest concentrations for $\mathrm{TN}$ were in the mixtures M1 and M2. The total time required for degradation of the OP waste was 13 weeks.
\end{abstract}

Keywords: precomposting; vermicomposting; orange peel waste; Eisenia fetida

\section{Introduction}

The orange (Citrus $\times$ sinensis) is a citrus fruit that is consumed all over the world in different ways [1]. In 2018-2019, the global production volume of fresh oranges was about 54.3 million metric tons [2]. Brazil is responsible for more than three-quarters of the orange juice produced worldwide and for $15 \%$ of the international exports of this product, followed by China, the United States, Mexico and some European countries [3,4].

During orange juice production, only around $50 \%$ of the weight of fresh oranges is transformed into juice. Subsequently, the process for obtaining juice generates large amounts of waste (peels, pulp, seeds, orange leaves and whole orange fruits that do not fulfill quality requirements). Orange peel (OP) waste constitutes approximately $50-60 \%$ of the weight of the processed fruit, composed of peels, tissue and the remaining portion of seeds [1,5]; it contains $75-85 \%$ water, $6-8 \%$ simple sugars (glucose, fructose and sucrose) and $1.53 \%$ polysaccharides (pectin, cellulose and hemicellulose). Its $\mathrm{pH}$ is $3-5$, and there is a significant presence of essential oil that is mainly composed of d-limonene (83-97\%) [6].

Different valorization routes have been proposed for OP waste, like biofuels, biorefinery, pectin extraction and animal feed, among others. Unfortunately, some of the aforementioned technologies are 
not economically sustainable for implementation on a full scale and are generally only suitable for large citrus processing plants; therefore, OP waste is usually used as forage or disposed of in landfills [5]. Thus, vermicomposting emerges as a viable alternative for the degradation and stabilization of organic matter (OM) [7]. It is defined as the biochemical process of OM degradation through interactions between earthworms and microorganisms, obtaining a final product with higher nutrient content in ionic forms and a humic substrate rich in bioactivity [8].

It is an economical and sustainable option for the use of organic waste, and it seeks to improve the content of organic matter, so it is one of the best options to substitute for the introduction of harmful chemical fertilizers into the soil [9]. Vermicompost does not require additional processing to be incorporated into the soil as long as it meets the specifications of not containing foreign mineral materials, organic materials not digested by earthworms, inert materials, viable seeds and live earthworms according to quality specifications [10]. The addition of compost to the soil will improve any soil's physical, chemical and biological properties [11,12]. It is excellent-quality humus that provides immediate results due to the fact that the plants absorb nutrients faster [13].

Besides, this process significantly reduces greenhouse gas (GHG) emissions by avoiding waste reaching landfills; this determines the elimination of the methane-generating source that results from anaerobic decomposition as well as $\mathrm{CO}_{2}$ and $\mathrm{N}_{2} \mathrm{O}$. These processes have very low emissions compared to those generated by untreated waste [14].

However, there are some negative environmental impacts that must be considered, such as transportation from the source to processing facilities as well as to vermicompost application sites, which could increase GHG emissions [15].

On the other hand, the literature consulted showed some studies related to the application of the vermicomposting process with OP waste, such as that by Favoretto et al., who considered this process an efficient technology to convert cattle manure waste mixed with OP and filter cake into organic fertilizer to reduce the incidence of soil pests [16]. Lee et al. investigated the suitability of orange skin to be reused as feedstock for Eudrilus eugeniae for 60 days, which revealed the potential of biotransforming orange skin into high-quality organic fertilizer [17]. Therefore, this research aims to study the operational conditions for the precomposting and vermicomposting processes using mixes of $\mathrm{OP}$ and vegetable waste in different proportions to obtain a quality vermicompost.

\section{Materials and Methods}

\subsection{Precomposting Process}

A total of $12 \mathrm{~kg}$ of OP waste was collected from a juice store and separated from the pulp. All the waste was finely chopped and disposed of in an $11.4 \mathrm{~L}$ capacity plastic container; this was placed on top of a table, and perforations were made in the bottom to collect the leachate generated. It was covered by a net to avoid the presence of pests such as insects or rodents. Subsequently, the container was tilted slightly for better drainage (Figure 1). During the precomposting process, the OP waste remained in this container for the necessary period of time before the vermicomposting process, and every third day, the container was sprayed with a sprinkler to maintain proper humidity levels $[18,19]$.

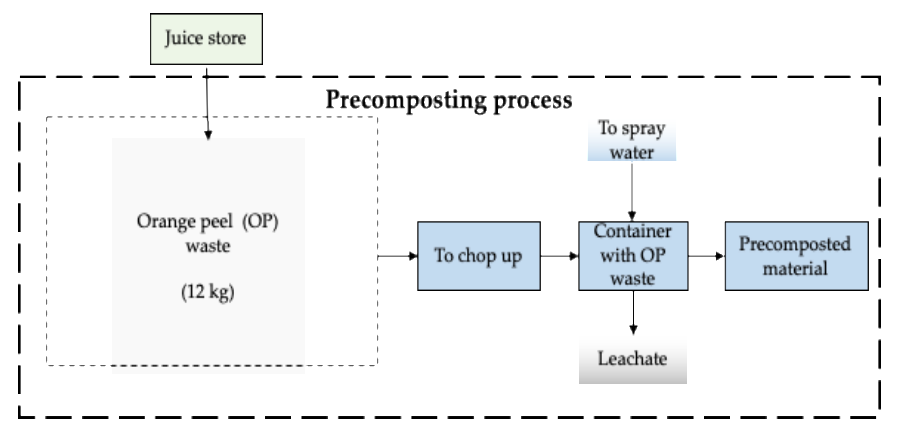

Figure 1. Precomposting process. Source: own elaboration. 


\subsection{Vermicomposting Process}

The purpose of the precomposting process mentioned in Section 2.1 was to avoid a temperature increase that could affect the earthworms and facilitate OP waste biodegradation [20,21]; afterwards, the vermicomposting process was performed. In addition, $10 \mathrm{~kg}$ of green waste was collected from local markets (vegetable waste from lettuce, chard, cabbage, spinach, celery, cress and broccoli), and $1 \mathrm{~kg}$ of eggshells (from the bakery) were dried in sunlight for $24 \mathrm{~h}[20,22-24]$; this is considered "load material" (LM). The addition of eggshells was due to their calcium $\left(\mathrm{Ca}^{+2}\right)$ content as well as proteins, glycoproteins and proteoglycans. In addition, $\mathrm{Ca}^{+2}$ is an important element in the worms' diet and can help their reproductive process $[22,25]$.

Experiments were conducted in four plastic containers, each with a $5.9 \mathrm{~L}$ capacity; they were adapted with holes that drained out to collect the leachates generated. All reactors were incubated in a dark place at environmental temperature. The first layer of soil $(1 \mathrm{~kg})$ was added to each of the four reactors, the second one was LM and the third layer was OP waste [26]. In the same way as was done during the precomposting process, water was sprayed every third day to maintain humidity levels. A total of 50 Eisenia fetida earthworms were collected in three plastic containers and transported to the site of the experiment (Figure 2).

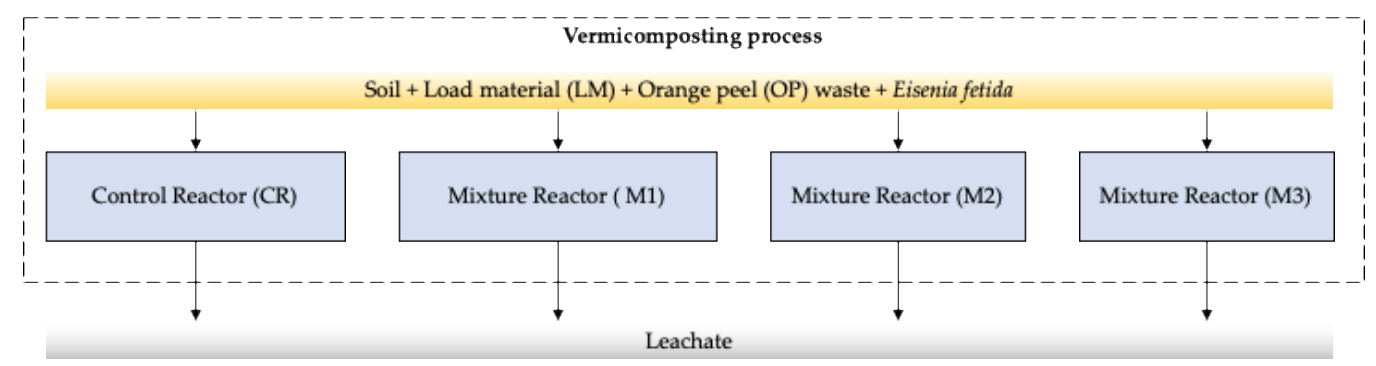

Figure 2. Vermicomposting process. Source: own elaboration.

The preparation for the reactors included the following combinations: (a) control reactor (CR)-50\% OP waste $(1 \mathrm{~kg})+50 \% \mathrm{LM}(1 \mathrm{~kg}),(\mathrm{b})$ mixture reactor (M1) - $50 \%$ OP waste $(1 \mathrm{~kg})+50 \% \mathrm{LM}(1 \mathrm{~kg})+50$ earthworms, (c) mixture reactor (M2) - $60 \%$ OP waste $(1.2 \mathrm{~kg})+40 \% \mathrm{LM}(0.8 \mathrm{~kg})+50$ earthworms and (d) mixture reactor (M3)—40\% OP waste $(0.8 \mathrm{~kg})+60 \% \mathrm{LM}(1.2 \mathrm{~kg})+50$ earthworms.

\subsection{Physicochemical Parameters and Sensory Specifications}

During the precomposting and vermicomposting processes, the following parameters were measured: temperature, $\mathrm{pH}$, humidity, $\mathrm{OM}$, total organic carbon (TOC), total nitrogen $(\mathrm{TN})$, the carbon/nitrogen $(\mathrm{C} / \mathrm{N})$ ratio (Table 1) and sensory characteristics (smell and color). The procedures were determined by Mexican Standard NMX-FF-109-SCFI-2007, "Vermicompost (worm casting)—specifications and test methods", and by local norms [10,27-29].

Table 1. Physicochemical parameters and tests.

\begin{tabular}{cc}
\hline Physicochemical Parameters & Test \\
\hline $\mathrm{pH}$ & Potentiometer \\
Temperature & Environmental thermometer \\
Humidity & Gravimetric method \\
Organic matter & By calcination \\
Total organic carbon & From the percentage of organic matter, \\
Total nitrogen & using the Van Bemmelen factor \\
& Kjendahl method \\
\hline & Source: own elaboration.
\end{tabular}




\subsection{Statistical Analysis}

The physicochemical parameters ( $\mathrm{pH}$, temperature and humidity) are presented in Excel charts including error bars to show standard deviation. Data generated (OM, TOC and TN) were subjected to an analysis of variance (ANOVA) and pairwise comparison using Tukey's test $(p<0.05)$. The JMP 8.0 software package was used. All tests were performed in triplicate.

\section{Results and Discussion}

\subsection{Precomposting Process}

For the OP precomposting process, a period of 42 days of stabilization was required, which was in the range of 42 to 45 days reported by Favoretto et al., Mahaly et al. and Huang et al., highlighting the importance of time for this process using waste with similar chemical characteristics $[16,26,30]$.

\subsubsection{Temperature}

Figure 3 shows the behavior of the environmental temperature and OP waste temperature, with values between 14 and $37.5^{\circ} \mathrm{C}$ during the six weeks of this process.

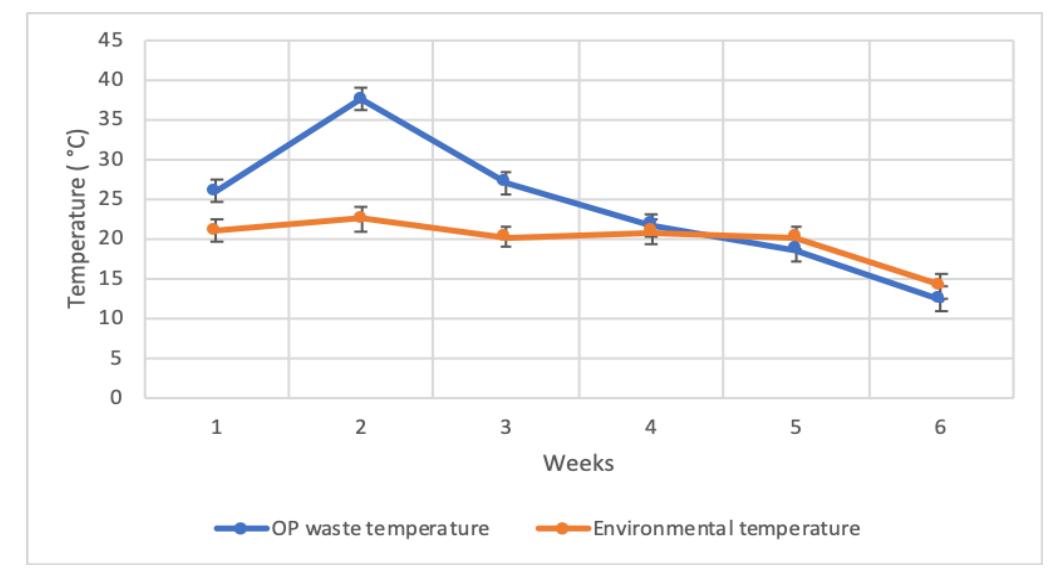

Figure 3. Temperature behavior in the precomposting process of orange peel (OP) waste.

This figure also shows that from weeks one to two, the OP waste temperature increased from 25.9 to $37.5^{\circ} \mathrm{C}$. This change was attributed to the biodegradation of organic substances; high temperatures constitute an indicator of success in the precomposting process [31-33]. This behavior has been reported in other studies, indicating that during the first five days of the precomposting process, temperatures increased from $20^{\circ} \mathrm{C}$ to more than $55^{\circ} \mathrm{C}$, which assured the reduction of pathogens [34].

During week four, the OP temperature values were close to the environmental temperature $\left(21.6^{\circ} \mathrm{C}\right)$ due to the loss of biodegradable substances, which indicated the achievement of the maturation phase $[35,36]$.

\subsection{2. $\mathrm{pH}$}

Figure 4 shows the changes in the $\mathrm{pH}$ of the OP waste; its initial value was 5.93, and on week two, it increased to 6.09, remaining at a value of 6 during the last four weeks.

Hanc and Chadimova reported, during a two-week experiment consisting of precomposting apple pomace, an increase in $\mathrm{pH}$ from 4.0 to 6.7 due to the degradation of $\mathrm{OM}$ [37]. The literature consulted indicated the optimum $\mathrm{pH}$ range is 6 to 8.5; it is related to the formation of ammonium ions during the degradation of $\mathrm{OM}$ and the consumption of organic acids by microorganisms in the precomposting process $[30,37,38]$. 
The decrease in $\mathrm{pH}$ may be due to the formation of $\mathrm{CO}_{2}$ and organic and humic acids $[26,27,32]$. When $\mathrm{pH}$ is 6 or above, it means that the $\mathrm{OM}$ is stabilized, and it is adequate for adding the earthworms into the vermicomposting process [39-41].

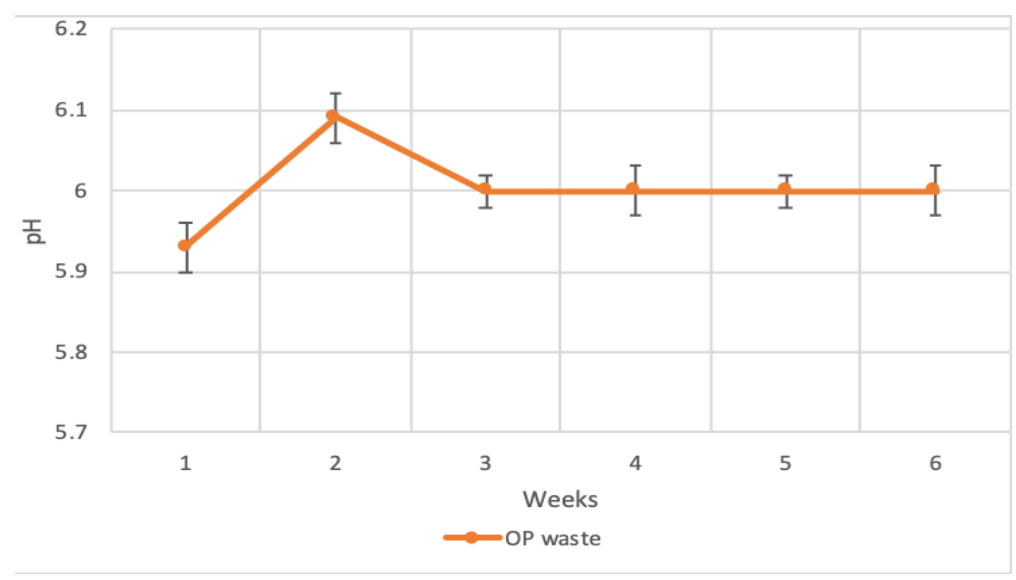

Figure 4. $\mathrm{pH}$ changes in precomposting OP waste.

\subsubsection{Humidity}

Figure 5 shows humidity behavior during OP waste precomposting. The humidity content was initially $84.12 \%$, and at the end, it was $80.29 \%$. Similar results have been reported for the precomposting process with fruit and vegetable waste, taking one to three weeks for humidity to decrease before conducting the vermicomposting process [32,42]. Based on the literature, humidity is an important factor, as it provides a medium for the transport of dissolved nutrients required for the metabolic and physiological activities of microorganisms. Nair et al. reported an initial humidity range between $80 \%$ and $85 \%$ for the precomposting process of food waste [43].

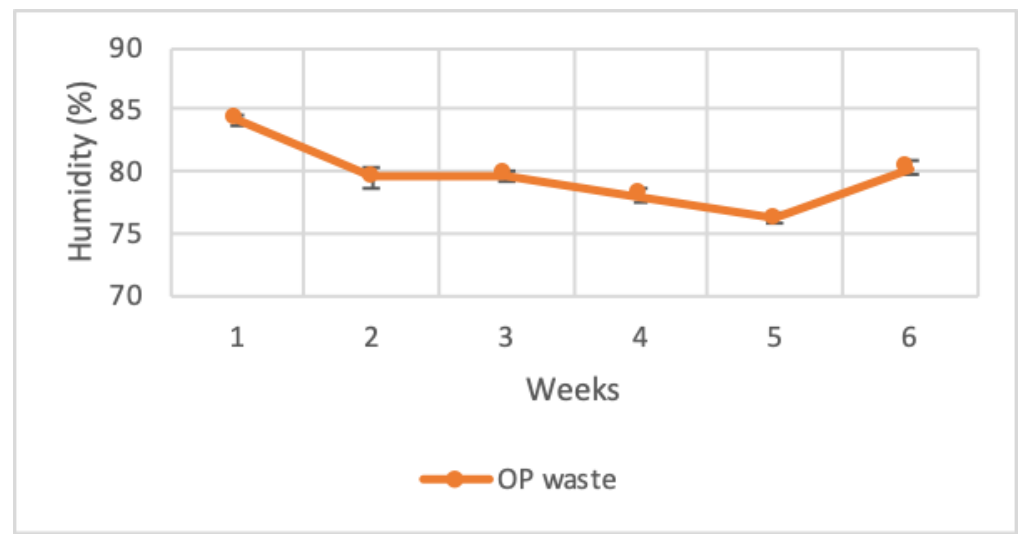

Figure 5. Humidity behavior during the precomposting process of OP waste.

3.1.4. Organic Matter (OM), Total Organic Carbon (TOC), Total Nitrogen (TN) and Carbon/Nitrogen $(\mathrm{C} / \mathrm{N})$ Ratio

The initial OM content for the OP waste was $78.33 \pm 1.84 \%$, while the final OM value was $72.30 \pm 1.58 \%$, representing the removal of $7.70 \%$. FAO indicates that $50-70 \%$ is ideal for the OM parameter in the first 2-5 days at the beginning of the process [23]. Another study obtained a final $\mathrm{OM}$ value of $87.33 \%$ in vegetable and cow dung precomposting after 15 days [44]. The OM content decreased due to its mineralization by microorganisms to provide energy for microbial growth and metabolism [45,46]. 
The TOC for the OP waste began at $45.43 \pm 0.84 \%$, coinciding with the $43.92 \%$ reported by Gelsomino et al. [47]. It is worth mentioning that TOC values can vary according to the parts integrated into the waste to be studied due to their physicochemical characteristics $[43,48]$. The final TOC for the OP waste was $41.96 \pm 0.69 \%$, which was similar to the $38.1 \%$ reported for the precomposting of vegetables, fruits, green waste and tea leaves [49]. The carbon loss was the result of waste degradation by the action of microorganisms and the elimination of precomposted material as $\mathrm{CO}_{2}$ and $\mathrm{CH}_{4}[45,50]$.

The initial value of $\mathrm{TN}$ was $1.3 \pm 0.02 \%$, similar to the $1.5 \%$ reported for OP waste [51]. The final value was $2.49 \pm 0.04 \%$, which coincided with the $2.10 \%$ obtained in the precomposting process of orange waste $[47,52]$. The increase in $\mathrm{TN}$ could be attributed to the formation of $\mathrm{NH}_{4}{ }^{+}$ions caused by the biodegradation of organic compounds $[38,53]$. The nitrogen flow is considered very efficient and effective when microorganisms are actively transforming the organic nitrogen; at the same time, plants are taking up the $\mathrm{NH}_{4}{ }^{+}$and $\mathrm{NO}_{3-}$ rapidly, which means the potential for nitrogen loss is relatively low [54].

The $\mathrm{C} / \mathrm{N}$ ratio at the beginning was 33.65 , which was in the recommended range of 25 to $30[45,55]$. At the end of the process, it decreased to the final value of 16.85. Kumar et al. reported a $\mathrm{C} / \mathrm{N}$ ratio of 18.5 in a precomposting process of green waste and food waste [53]. According to several authors, a low $\mathrm{C} / \mathrm{N}$ ratio is related to a stabilized product $[48,55]$. It has also been reported that the loss of $\mathrm{OM}$ decreases the weight of the precomposted material and reduces the $\mathrm{C} / \mathrm{N}$ ratio [46]. Therefore, the final values obtained from this process were suitable for the vermicomposting process [56].

\subsubsection{Sensory Characteristics of Precomposting}

The change in the OP waste during the precomposting process is shown in Figure 6. On week one, the original color was orange, and its consistency was flexible, while on week six, it turned orange and brown and became rigid [32].

At the beginning of the experiment, the waste gave off penetrating odors; over time, they decreased, leading to an odor-free product. It is worth mentioning that the weight of the OP waste on week one was $10 \mathrm{~kg}$, and on week six, it was $4 \mathrm{~kg}$ (a 60\% reduction in weight) [57].
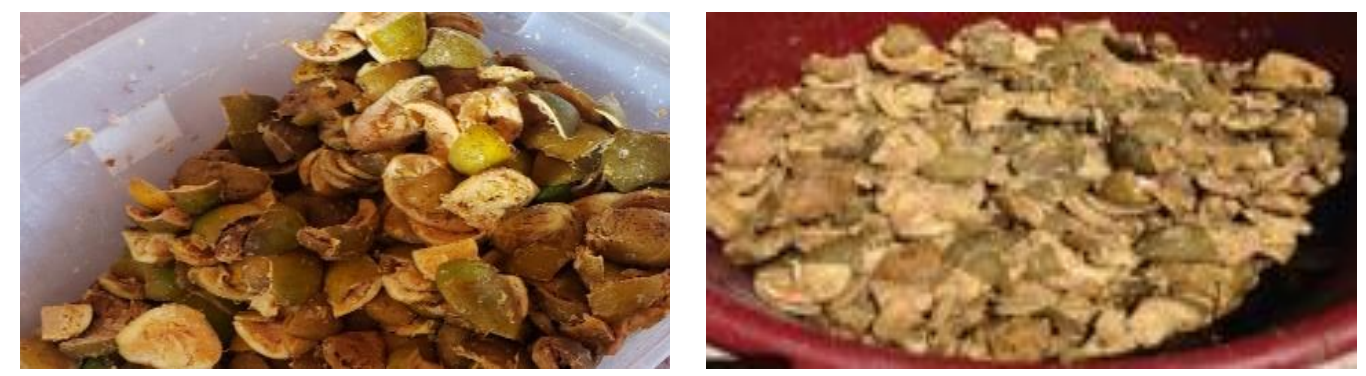

Figure 6. OP waste on weeks one and six of the precomposting process.

\subsection{Vermicomposting Process}

\subsubsection{Temperature}

Figure 7 shows the behavior of the temperature of the OP waste in the four mixtures (CR, M1, M2 and M3) during the vermicomposting process, which was performed for seven weeks. The four mixtures remained in the range of 20.96 to $22.2^{\circ} \mathrm{C}$ during the first four weeks. From weeks five to seven, there were lower values in the range of 14.1 to $16.58^{\circ} \mathrm{C}$, mainly due to the climatic conditions.

Similar behavior was reported during the vermicomposting process using rice straw and cow manure waste, with an initial temperature of $27.5^{\circ} \mathrm{C}$ and a final one of $17^{\circ} \mathrm{C}$, indicating that when the temperature decreased to values close to environmental temperature, the degradation of $\mathrm{OM}$ had almost completed and stabilized [58,59]. 
According to the literature, the temperature for earthworm development should not exceed $27^{\circ} \mathrm{C}$, and it must not be under $9{ }^{\circ} \mathrm{C}$ because it could cause their death $[18,60]$. The temperature values of the four mixtures stayed in this range, improving the microbial activity and the growth of earthworms, which could quickly stabilize the waste in the mixtures $[18,61]$.

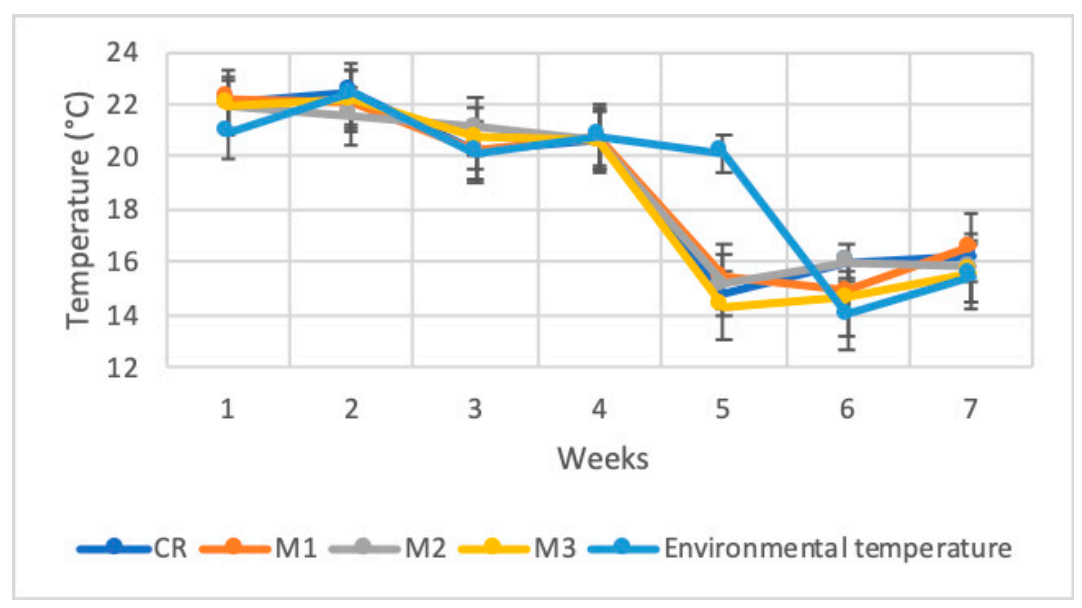

Figure 7. Temperature changes in the vermicomposting process of OP waste.

\subsection{2. $\mathrm{pH}$}

Figure 8 shows the $\mathrm{pH}$ during the seven weeks of the vermicomposting process for the OP waste in the four mixtures registered values from 6.52 to 7.5 . The $\mathrm{pH}$ at the end of the precomposting process was 6 (Figure 3); however, when the LM and the eggshells were added, the $\mathrm{pH}$ increased until it reached 6.5 to 7.2 , corresponding to the initial $\mathrm{pH}$ values from this process. This change was probably due to the contribution of the eggshells, with a $\mathrm{pH}$ of $10.3[17,62]$. The final values from the process were from 7 to 7.3. The changes in $\mathrm{pH}$ were due to the degradation of OM through the release of organic acids and the mineralization of nitrogen [63,64].

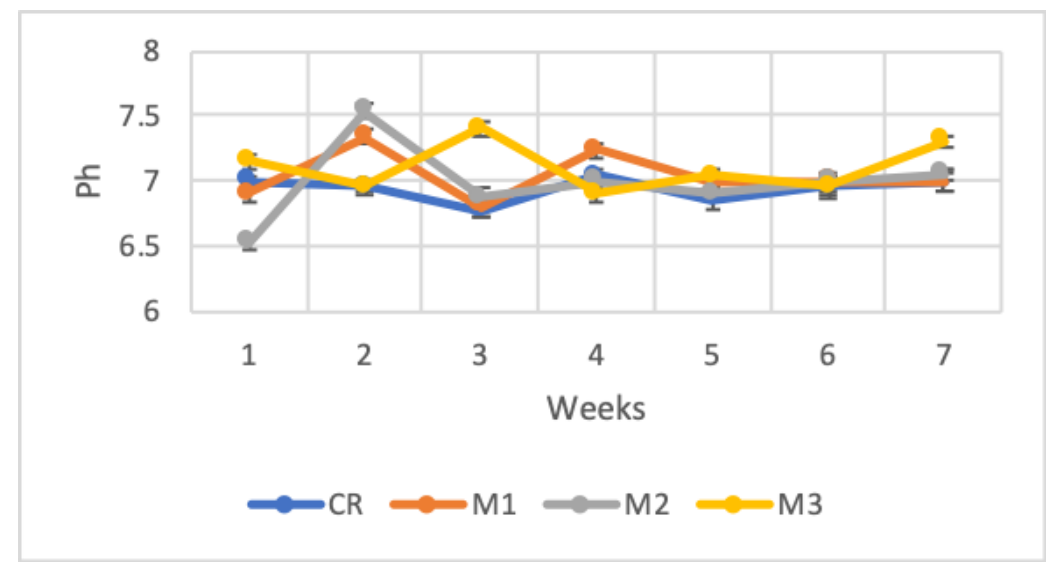

Figure 8. $\mathrm{pH}$ changes during the vermicomposting process of $\mathrm{OP}$ waste.

Similar results have been reported during the vermicomposting process with green waste, cattle manure and dried leaves, with an initial $\mathrm{pH}$ of 6.1 and a final $\mathrm{pH}$ of 7.10, indicating that this increase in $\mathrm{pH}$ was dynamic and dependent on the substrate due to the mineralization of the protein that produces alkaline ammonia or the loss of volatile acids with $\mathrm{CO}_{2}$ release. The decreasing values could be because of the production of humic and fulvic acids [58,63]. Several authors have reported the adequate $\mathrm{pH}$ range for the vermicomposting process is between 5.5 and $8.0[18,65]$. 


\subsubsection{Humidity}

Figure 9 shows the humidity content in the four mixtures (CR, M1, M2 and M3) registered for the vermicomposting process, which remained within the range of $42.5 \%$ to $83.6 \%$. CR and M1 had the lowest humidity content during the first four weeks. M2 and M3 showed the highest percentage of humidity during the whole process.

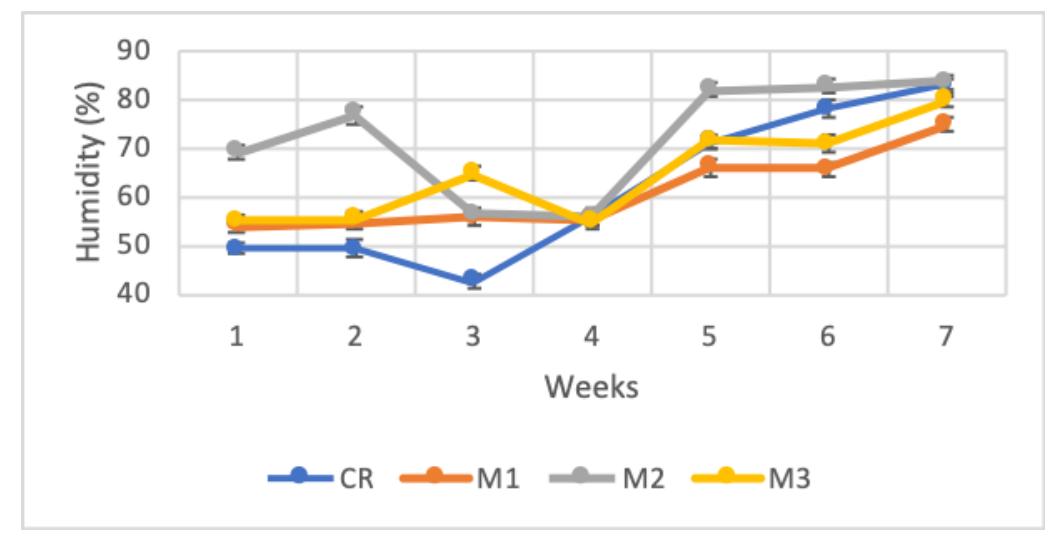

Figure 9. Humidity content during the process of vermicomposting of OP waste.

In the first four weeks, low humidity contents were registered, probably as a consequence of the biodegradation of OM during the vermicomposting process [66]. The humidity content is crucial for the controlled evolution of the biodegradation process [67]. According to the literature consulted, most of the authors reported humidity values from $60 \%$ to $80 \%$, indicating a suitable environment for the rapid growth of Eisenia fetida to ensure their optimal survival [57,59].

3.2.4. Organic Matter (OM), Total Organic Carbon (TOC), Total Nitrogen (TN) and Carbon/Nitrogen $(\mathrm{C} / \mathrm{N})$ Ratio

The physicochemical characteristics, OM, TOC, TN and the C/N ratio, of the four mixes (CR, M1, M2 and M3) studied before the vermicomposting process are shown in Table 2. These were determined using the precomposted material added with the LM in the percentages indicated under the table.

Table 2. Characteristics of the four mixtures with OP waste before vermicomposting.

\begin{tabular}{ccccc}
\hline Parameters & CR & M1 & M2 & M3 \\
\hline OM (\%) & $76.97 \pm 1.20 \mathrm{a}$ & $76.97 \pm 1.20 \mathrm{a}$ & $73.93 \pm 1.22 \mathrm{~b}$ & $72.88 \pm 1.16 \mathrm{~b}$ \\
TOC (\%) & $44.65 \pm 0.71 \mathrm{a}$ & $44.65 \pm 0.71 \mathrm{a}$ & $42.89 \pm 0.91 \mathrm{~b}$ & $42.28 \pm 0.67 \mathrm{~b}$ \\
TN (\%) & $2.12 \pm 0.04 \mathrm{a}$ & $2.12 \pm 0.04 \mathrm{a}$ & $1.20 \pm 0.02 \mathrm{~b}$ & $1.60 \pm 0.03 \mathrm{c}$ \\
C/N Ratio & 24.93 & 24.93 & 38.20 & 26.16 \\
\hline
\end{tabular}

$\mathrm{CR}=$ control reactor-50\% OP, 50\% load material $(\mathrm{LM}) ; \mathrm{M} 1=$ reactor $-50 \% \mathrm{OP}, 50 \% \mathrm{LM} ; \mathrm{M} 2=$ reactor- $-60 \%$ OP, $40 \% \mathrm{LM}$; and M3 = reactor- $40 \% \mathrm{OP}, 60 \% \mathrm{LM}$. Mean values (mean $\pm \mathrm{SD}, n=3$ ) followed by different letters are statistically different (analysis of variance (ANOVA); Tukey's test, $p<0.05$ ).

Table 3 shows the values obtained at the end of the seven weeks of the vermicomposting process for the four mixes.

On the first week, the four mixtures, CR, M1, M2 and M3, initially registered an OM content of $76.97 \%, 76.97 \%, 73.93 \%$ and $72.88 \%$, respectively (Table 2), ending with $63.79 \%, 64 \%, 65.80 \%$ and $64.88 \%$ (Table 3). M2 and M3 were the mixtures with the highest percentages of removal, with $11 \%$ and $10.97 \%$, respectively. 
Table 3. Characteristics of the four mixtures with OP waste after vermicomposting.

\begin{tabular}{ccccc}
\hline Parameters & CR & M1 & M2 & M3 \\
\hline OM $(\%)$ & $63.79 \pm 0.78 \mathrm{a}$ & $64 \pm 1.14 \mathrm{a}$ & $65.80 \pm 0.69 \mathrm{a}$ & $64.88 \pm 0.86 \mathrm{a}$ \\
TOC $(\%)$ & $37 \pm 0.64 \mathrm{a}$ & $37.13 \pm 0.71 \mathrm{a}$ & $38.17 \pm 0.53 \mathrm{a}$ & $37.64 \pm 0.79 \mathrm{a}$ \\
TN $(\%)$ & $3.50 \pm 0.08 \mathrm{a}$ & $4.50 \pm 0.10 \mathrm{~b}$ & $6.30 \pm 0.13 \mathrm{c}$ & $3.78 \pm 0.09 \mathrm{~d}$ \\
C/N Ratio & 11.74 & 8.80 & 6.05 & 9.95 \\
\hline
\end{tabular}

$\mathrm{CR}=$ control reactor-50\% OP, $50 \% \mathrm{LM} ; \mathrm{M} 1=$ reactor-50\% OP, $50 \% \mathrm{LM} ; \mathrm{M} 2=$ reactor- $60 \% \mathrm{OP}, 40 \% \mathrm{LM}$; and M3 $=$ reactor $-40 \%$ OP, $60 \%$ LM. Mean values (mean $\pm \mathrm{SD}, n=3$ ) followed by different letters are statistically different (ANOVA; Tukey's test, $p<0.05$ ).

Other authors have also reported a decrease in OM percentages, with an initial content of $95 \%$ and a final one of $55.3 \%$ for the vermicomposting process with fruit and vegetable waste $[60,68]$. The loss of OM during the vermicomposting process was attributed to the synergistic effect of the earthworms and microorganisms $[19,68]$.

The OM percentage at the beginning of the vermicomposting process was significantly different between the mixtures CR and M1 in comparison to M2 and M3. However, the final OM values for the four mixtures did not have significant differences.

At the beginning, the mixtures CR, M1, M2 and M3 had TOC values of $44.65 \%, 44.65 \%, 42.89 \%$ and $42.28 \%$ (Table 2), and at the end, the values were $37 \%, 37.13 \%, 38.17 \%$ and $37.64 \%$ (Table 3 ), respectively, with percentages of removal of $17.13 \%, 16.84 \%, 11 \%$ and $10.97 \%$. CR had the highest percentage of removal.

The initial TOC content values for the four mixtures decreased, coinciding with the information reported in the literature due to the combined action of earthworms and microorganisms, resulting in the homogenization, fragmentation and mineralization of organic materials, which in turn significantly reduced OM $[65,69]$. The decrease in TOC values can be attributed to the degradation of OM as a result of the conversion to carbon dioxide by earthworms and microbial respiration as well as assimilation in the form of biomass $[63,70]$.

Initial TOC percentages for all four mixtures showed significant differences between the CR and M1 mixtures compared to M2 and M3. Regarding the final TOC values, there was no significant difference.

CR, M1, M2 and M3 had initial TN values of $2.12 \%, 2.12 \%, 1.20 \%$ and $1.60 \%$ (Table 2) and final contents of $3.50 \%, 4.50 \%, 6.30 \%$ and $3.78 \%$ (Table 3), respectively. In the four mixtures, the initial TN content indicated the existence of adequate conditions for the vermicomposting process. The increase in the TN concentrations at the end of the process was due to the loss of carbon in the form of $\mathrm{CO}_{2}$ through the decomposition of the substrate. Besides, the excreta and polysaccharides of earthworms as well as tissue decomposition from dead earthworms enriched the TN concentration in the reactors $[21,66,71,72]$

The results obtained in this research also coincided with other experiments with OP waste, cattle manure and filter cake, reporting an initial TN content of $1.57 \%$ with variations throughout the process, finally obtaining $3.37 \%$ in 105 days [16,73].

The initial concentrations of TN among M1, M2 and M3 had significant differences. Among the CR and M1 mixtures, there was no such difference. Regarding the final values, the four mixtures had significant differences. It is important to highlight that the highest concentrations were in the mixtures M1 and M2.

The initial C/N ratio of the four mixtures was 24.93 (CR), 24.93 (M1), 38.20 (M2) and 26.16 (M3) (Table 2), coinciding with values of 23 (cow dung and green waste) and 29.10 (green waste, dry leaves, small branches and paper sheets) and corresponding to a great loss of carbon accompanied by a nitrogen increase $[16,32,64,69]$.

The final values of the $\mathrm{C} / \mathrm{N}$ ratio for the four mixtures were $11.74(\mathrm{CR}), 8.8$ (M1), 6.05 (M2) and 9.95 (M3) (Table 3). The decrease in the $\mathrm{C} / \mathrm{N}$ ratio was attributed to the continuous loss of carbon as $\mathrm{CO}_{2}$ through microbial respiration and nitrogen production during the process [72]. The values registered in this experiment were under the value of 20 that is indicated by Mexican Standard NMX-FF-109-SCFI-2007 for quality vermicompost [10]. The decrease in the C/N ratio is indicative of 
increased humification of $\mathrm{OM}$, which is related to the quality and maturity of vermicompost $[16,21,32,74]$. Other studies reported that a $\mathrm{C} / \mathrm{N}$ ratio lower than 20 was adequate in the vermicomposting process due to a stable evolution of the degradation process and mature vermicompost [74]. The application of vermicompost with a low $\mathrm{C} / \mathrm{N}$ ratio has a beneficial impact on the soil [75].

\section{Conclusions}

Throughout this experiment, it was demonstrated that the vermicomposting process was feasible for degrading OP waste, obtaining a quality product according to the final physicochemical characteristics to be applied as a soil improver. The LM added to all the mixtures contributed to enriching the characteristics of the substrate to balance the nutrients required for a biological process.

The precomposting process was necessary to make the substrate adequate in such a way that the earthworms could degrade the OM efficiently, facilitating the vermicomposting process.

The precomposting and vermicomposting processes are extremely sensitive; for this reason, the monitoring of the parameters of temperature, $\mathrm{pH}, \mathrm{OM}, \mathrm{TOC}, \mathrm{TN}$ and the $\mathrm{C} / \mathrm{N}$ ratio was crucial to keep them under control.

All the mixtures had final values between the range established for quality and mature vermicompost; however, the highest concentrations for TN were in the mixtures M1 and M2.

The vermicomposting process is a viable alternative to valorize $\mathrm{OP}$ waste, contributing to an integral treatment to avoid inadequate final disposal that generates environmental impacts on the air, soil and water.

Author Contributions: Conceptualization, L.D.M.-S., M.R.G.-D. and E.C.-G.; methodology, E.C.-G.; formal analysis, E.C.-G.; writing — original draft preparation, L.D.M.-S.; writing — review and editing, L.D.M.-S., M.R.G.-D. and E.C.-G.; resources, E.C.-G.; validation, E.C.-G.; supervision, M.R.G.-D.; data curation, L.E.M.-M.; project administration, L.D.M.-S.; investigation, L.E.-M.M. All authors have read and agreed to the published version of the manuscript.

Funding: This research was funded by Universidad Veracruzana.

Conflicts of Interest: The authors declare no conflict of interest.

\section{References}

1. Rezzadori, K.; Benedetti, S.; Amante, E.R. Proposals for the residues recovery: Orange waste as raw material for new products. Food Bioprod. Process. 2012, 90, 606-614. [CrossRef]

2. Shahbandeh, M. Orange juice production volume worldwide from 2014/2015 to 2018/2019 (in million metric tons). Food Nutr. 2019. Available online: https://www.statista.com/statistics/1044906/world-orange-juiceproduction/ (accessed on 15 June 2020).

3. Caserta, R.; Teixeira, S.N.S.; Granato, L.M.; Dorta, S.O.; Rodrigues, C.M.; Mitre, L.K.; Yochikawa, J.T.H.; Fischer, E.R.; Nascimento, C.A.; Souza, N.R.R.; et al. Citrus biotechnology: What has been done to improve disease resistance in such an important crop? Biotechnol. Res. Innov. 2020, 54, 95-109. [CrossRef]

4. USDA/FAS Foreign Agricultural Services. Citrus: World Markets and Trade 2019. Available online: https://apps.fas.usda.gov/psdonline/circulars/citrus.pdf (accessed on 18 June 2020).

5. Negro, V.; Ruggeri, B.; Fino, D.; Tonini, D. Life cycle assessment of orange peel waste management. Resour. Conserv. Recycl. 2017, 127, 148-158. [CrossRef]

6. Calabrò, P.S.; Paone, E.; Komilis, D. Strategies for the sustainable management of orange peel waste through anaerobic digestion. J. Environ. Manag. 2018, 212, 462-468. [CrossRef] [PubMed]

7. Lazcano, C.; Gómez-Brandón, M.; Domínguez, J. Comparison of the effectiveness of composting and vermicomposting for the biological stabilization of cattle manure. Chemosphere 2008, 72, 1013-1019. [CrossRef] [PubMed]

8. Pramanik, P.; Safique, S.; Jahan, A.; Bhagat, R.M. Effect of vermicomposting on treated hard stem leftover wastes from pruning of tea plantation: A novel approach. Ecol. Eng. 2016, 97, 410-417. [CrossRef]

9. Castillo, B.E.; López, G.R.C. Planta de Lombricomposteo "Beneficio de Mejora de Suelo en Zona de Trabajo Ejidal"; Universidad Autónoma Metropolitana: Ciudad de México, Mexico, 2010; Available online: http://www.pa. gob.mx/publica/rev_46/an\%C3\%A1lisis/Erika_Castillo_Brise\%C3\%B1o.pdf (accessed on 27 August 2020). 
10. SCFI. Norma Mexicana NMX-FF-109-SCFI-2007.Vermicompost (Worm Casting)—Specifications and Test Methods; Secretaría de Comercio y Fomento Industrial, Diario Oficial de la Federación: Mexico City, Mexico, 2007; Available online: http://www.economia-nmx.gob.mx/normas/nmx/2007/nmx-ff-109-scfi-2008.pdf (accessed on 15 June 2020).

11. US Composting Council. Compost. The Sustainable Solutions Soil Water Plants. 2013. Available online: https://www.compostfoundation.org/Portals/2/Images/Increasing\%20the\%20OM\%20in\%20Soil\% 207\%2002\%2014\%20CURRENT.pdf (accessed on 27 August 2020).

12. Jack, A.L.H.; Thies, J.E. Compost and Vermicompost as Amendments Promoting Soil Health. Biological Approaches to Sustainable Soil Systems; CRC Press: Boca Raton, FL, USA, 2006.

13. SEMARNAT. Residuos. Secretaría de Medio Ambiente y Recursos Naturales. Mexico, 2008. Available online: https://apps1.semarnat.gob.mx:8443/dgeia/informe_2008_ing/pdf/cap_7_residuos.pdf (accessed on 27 August 2020).

14. Racines, C.A.V.D.R. Análisis de Reducción de Emisiones de Gases de Efecto Invernadero Mediante. Descomposición Aeróbica de Residuos Industriales en Mezcla con Residuos Pecuarios. Master's Thesis, Universidad Andina Simón Bolívar, Bolivia, Ecuador, 2018. Available online: http://repositorio.uasb.edu.ed/ handle/10644/6058 (accessed on 27 August 2020).

15. Martínez-Blanco, J.; Muñoz, P.; Antón, A.; Rieradevall, J. Life cycle assessment of the use of compost from municipal organic waste for fertilization of tomato crops. Resour. Conserv. Recycl. 2009, 53, 340-351. [CrossRef]

16. Favoretto, P.L.B.; Ademola, I.A.; Abosede, O.O.; Vinicius, B.A.; Olimpia, O.R.M. Chemical study of vermicomposted agroindustrial wastes. Int. J. Recycl. Org. Waste Agric. 2016, 5, 55-63.

17. Lee, L.H.; Wu, T.Y.; Low, Z.X. Reuse of Powdered Eggshells in Vermicomposting of Acidic Waste; Monash University: Bandar Sunway, Malaysia, 2015; Available online: https:/www.semanticscholar.org/paper/Reuseof-powdered-eggshells-in-vermicomposting-of-Lee-Wu/5254fdc716e9032c87544028e33dfd8bc7a30146 (accessed on 27 August 2020).

18. Hanc, A.; Vasak, F. Processing separated digestate by vermicomposting technology using earthworms of the genus Eisenia. Int. J. Environ. Sci. Technol. 2015, 12, 1183-1190. [CrossRef]

19. Rogayan, D.V., Jr.; Tomboc, E.H.F.; Paje, A.V.; Lim, K.L.P.; Ararro, J.A.R.; Ocampo, J.G.; Gregorio, H.S. Vermiculture and Vermicomposting; Ramon Magsaysay Technological University: San Marcelino, Zambales, 2010; Available online: https://www.researchgate.net/publication/333892881_Vermiculture_and_ Vermicomposting (accessed on 5 June 2020).

20. Mikolic, C.; Ruffinelli, S.; Dardano, B.; Escudero, G.J.; Andreoni, I.; Gómez, A.; Basile, D. Manual de Vermicompostaje: Cómo Reciclar Nuestros Residuos Orgánicos; Departamento de Desarrollo Ambiental: Montevideo, Uruguay, 2018; Available online: https://montevideo.gub.uy/sites/default/files/biblioteca/ imvermicompostajeinterior.pdf (accessed on 18 June 2020).

21. Pattnaik, S.; Reddy, V. Nutrient Status of Vermicompost of Urban Green Waste Processed by Three Earthworm Species-Eisenia fetida, Eudrilus eugeniae, and Perionyx excavates. Appl. Environ. Soil Sci. 2010, 2010, 967526. [CrossRef]

22. Castro, A.R.; Cova, L.J.; García, D.E.; Medina, M.G. Efecto de la cáscara de huevo en la producción de cápsulas de la lombriz roja (Eisenia andrei). Zootec. Trop. 2007, 25, 135-142.

23. FAO. Manual de Compostaje del Agricultor: Experiencias en América Latina; Food and Agriculture Organization: Santiago, Chile, 2013; Available online: http://www.fao.org/3/a-i3388s.pdf (accessed on 18 June 2020).

24. Nagavallemma, K.P.; Lacroix, S.; Vineela, C.; Sahrawat, K.L.; Padmaja, V.V.; Rao, B.M.; Wani, S.P. Vermicomposting: Recycling Wastes into Valuable Organic Fertilizer. Global Themeon Agrecosystems Report no. 8. Patancheru 502 324; International Crops Research Institute for the Semi-Arid Tropics: Andhra Pradesh, India, 2006; Volume 2, pp. 1-16.

25. Hincke, M.T.; Nys, Y.; Gautron, J. The role of matrix proteins in eggshell formation. Jpn. Poult. Sci. Assoc. 2010, 47, 208-219. [CrossRef]

26. Huang, K.; Li, F.; Wei, Y.; Fu, X.; Chen, X. Effects of inoculation with Phanerochaete chrysosporium at various time points on enzyme activities during agricultural waste composting. Bioresour. Technol. 2014, 101, $222-227$.

27. SEMARNAT. Norma Oficial Mexicana NOM-02-RECNAT-2000. Especificaciones de Fertilidad, Salinidad y Clasificación de Suelos. Estudios, Muestreo y Análisis; Secretaría de Medio Ambiente y Recursos Naturales, Diario Oficial de la Federación: Mexico City, Mexico, 2002. 
28. SCFI. Norma Mexicana NMX-F-066-S-1978. Determinación de Cenizas; Secretaría de Comercio y Fomento Industrial, Diario Oficial de la Federación: Mexico City, Mexico, 1978.

29. SEDUE. Norma Mexicana NMX-AA-24-1984. Protección al Ambiente-Contaminación del Suelo-Residuos Sólidos Municipales-Determinación de Nitrógeno Total; Secretaría de Desarrollo Urbano y Ecología, Diario Oficial de la Federación: Mexico City, Mexico, 1992.

30. Mahaly, M.; Senthilkumar, A.K.; Arumugam, S.; Kaliyaperumal, C.; Karupannan, N. Vermicomposting of distillery sludge waste with tea leaf residues. Sustain. Environ. Res. 2018, 1, 223-227. [CrossRef]

31. Ros, M.; García, C.; Hernández, T. A full-scale study of treatment of pig slurry by composting: Kinetic changes in chemical and microbial properties. Waste Manag. 2006, 26, 1108-1118. [CrossRef]

32. Sepúlveda, V.L.A.; Alvarado, T.J.A. Manual de Aprovechamiento de Residuos Orgánicos a Través de Sistemas de Compostaje y Lombricultura en el Valle de Aburrá, Medellín, Colombia 2013. Available online: http://www.earthgreen.com.co/descargas/manual-compostaje.pdf (accessed on 20 April 2020).

33. Castillo-González, E.; Giraldi-Díaz, M.R.; De Medina-Salas, L.; Sánchez-Castillo, M.P. Pre-Composting and Vermicomposting of Pineapple (Ananas comosus) and Vegetable Waste. Appl. Sci. 2019, 9, 3564. [CrossRef]

34. Azim, K.; Soudi, B.; Boukhari, S.; Perissol, C.; Roussos, S.; Thami, A.I. Composting parameters and compost quality: A literature review. Org. Agric. 2018, 8, 141-158. [CrossRef]

35. Yang, F.; Li, Y.; Han, Y.; Qian, W.; Li, G.; Luo, W. Performance of manure to control gaseous emissions in kitchen waste composting. Sci. Total Environ. 2019, 657, 262-269. [CrossRef]

36. Swarnam, T.P.; Velmurugan, A.; Kumar, P.S.; Dam, R.S. Enhancing nutrient recovery and compost maturity of coconut husk by vermicomposting technology. Bioresour. Technol. 2016, 207, 76-84. [CrossRef]

37. Hanc, A.; Chadimova, Z. Nutrient recovery from Apple pomace waste by vermicomposting technology. Bioresour. Technol. 2014, 168, 240-244. [CrossRef] [PubMed]

38. Rékási, M.; Mazsu, M.; Draskovits, E.; Bernhardt, B.; Szabó, A.; Rivier, P.A.; Farkas, C.; Borsányi, B.; Pirkó, B.; Molnár, S.; et al. Comparing the agrochemical properties of compost and vermicomposts produced from municipal sewage sludge digestate. Bioresour. Technol. 2019, 291, 121861. [CrossRef] [PubMed]

39. Hanc, A.; Pliva, P. Vermicomposting technology as a tool for nutrient recovery from kitchen bio-waste. J. Mater. Cycles Waste Manag. 2013, 15, 431-439. [CrossRef]

40. Bhat, S.A.; Singh, J.; Vig, A.P. Potential utilization of bagasse as feed material for earthworm Eisenia fetida and production of vermicompost. SpringerPlus 2015, 4, 2-9. [CrossRef]

41. Acosta, D.C.M.; Solís, P.O.; Villegas, T.O.G.; Cardoso, V.L. Precomposteo de residuos orgánicos y su efecto en la dinámica poblacional de Eisenia foetida. Agron. Costarric. 2013, 37, 127-139.

42. Li, W.; Ahmad, S.B.; Li, J.; Cui, G.; Wei, Y.; Yamada, T.; Li, F. Effect of excess activated sludge on vermicomposting of fruit and vegetable waste by using novel vermireactor. Bioresour. Technol. 2020, 302, 122816. [CrossRef]

43. Nair, J.; Sekiozoic, V.; Anda, M. Effect of pre-composting on vermicomposting of kitchen waste. Bioresour. Technol. 2006, 97, 2091-2095. [CrossRef]

44. Taeporamaysamai, O.; Ratanatamskul, C. Co-composting of various organic substrates from municipal solid waste using an on-site prototype vermicomposting reactor. Int. Biodeterior. Biodegrad. 2016, 113, 357-366. [CrossRef]

45. Li, G.; Zhu, Q.; Jiang, Z.; Li, M.; Ma, C.; Li, X.; Liu, H.; Liu, Y.; Li, Q. Roles of non-ionic surfactant sucrose ester on the conversion of organic matters and bacterial community structure during composting. Bioresour. Technol. 2020, 308, 123279. [CrossRef]

46. Ameen, A.; Ahmad, J.; Raza, S. Determination of total organic matter of mature compost prepared by using municipal solid waste. Int. J. Sci. Res. Publ. 2016, 6, 293-295.

47. Gelsomino, A.; Abenavoli, M.R.; Princi, G.; Anttina, E.; Cacco, G.; Sorgoná, A. Compost from Fresh Orange Waste: A Suitable Substrate for Nursery and Field Crops? Compos. Sci. Util. 2010, 18, 201-210. [CrossRef]

48. Oviedo, O.E.R.; Domínguez, I.; Komilis, D.; Sánchez, A. Co-composting of Green Waste Mixed with Unprocessed and Processed Food Waste: Influence on the Composting Process and Product Quality. Waste Biomass Valor 2019, 10, 63-74. [CrossRef]

49. Kucbel, M.; Raclavská, H.; Růžičková, J.; Švédová, B.; Sassmanová, V.; Drozdová, J.; Raclavský, K.; Juchelková, D. Properties of composts from household food waste produced inautomatic composters. J. Environ. Manag. 2019, 236, 657-666. [CrossRef] [PubMed] 
50. Tiquia, S.M.; Richard, T.L.; Honeyman, M.S. Carbon, nutrient, and mass loss during composting. Nutr. Cycl. Agroecosystems 2002, 62, 15-24. [CrossRef]

51. Pathak, P.D.; Mandavgane, S.A.; Kulkarni, B.D. Fruit peel waste: Characterization and its potential uses. Curr. Sci. 2017, 113, 1-11. [CrossRef]

52. Ren, L.; Cai, C.; Zhang, J.; Yang, Y.; Wu, G.; Luo, L.; Huang, H.; Zhou, Y.; Qin, P.; Yuc, M. Key environmental factors to variation of ammonia-oxidizing archaea community and potential ammonia oxidation rate during agricultural waste composting. Bioresour. Technol. 2018, 270, 278-285. [CrossRef]

53. Kumar, M.; Liang, O.Y.; Gaw, L.J. Co-composting of green waste and food waste at low C/N ratio. Waste Manag. 2010, 30, 602-609. [CrossRef] [PubMed]

54. Lim, L.Y.; Tin, L.C.; Phun, C.B.C.; Shiun, L.J.; Roji, S.M.; Jaromír, K.J. A review on the impacts of compost on soil nitrogen dynamics. Chem. Eng. Trans. 2018, 63, 349-354.

55. Lima, J.Z.; Raimondia, I.S.; Schalchb, V.; Rodriguesa, V.G.S. Assessment of the use of organic composts derived from municipal solid waste for the adsorption of $\mathrm{Pb}, \mathrm{Zn}$; Cd. J. Environ. Manag. 2018, 226, 386-399. [CrossRef]

56. Neugebauera, M.; Sołowieja, P.; Piechockia, P.; Czekałab, W.; Janczak, D. The influence of the C: N ratio on the composting rate. Int. J. Smart Grid Clean Energy 2017, 2, 54-60. [CrossRef]

57. Zhang, H.; Li, J.; Zhang, Y.; Huang, K. Quality of vermicompost and Microbial Community Diversity Affected by the Contrasting Temperature during Vermicomposting of Dewateres Sludge. Int. J. Environ. Res. Public Health 2020, 17, 1748. [CrossRef]

58. Indrani, R.Y.; Adil, A.A.; Ori, L. Vermicomposting of different organic materials using the epigeic earthworm Eisenia foetida. Int. J. Recycl. Org. Waste Agric. 2018, 1, 23-36.

59. Stewart, W.S.S. Efficacy of organic amendments used in containerized plant production: Part 1-Compost-based amendments. Sci. Hortic. 2020, 266, 108856. [CrossRef]

60. Lleó, T.; Albacete, E.; Barrena, R.; Font, X.; Artola, A.; Sánchez, A. Home and vermicomposting as sustainable options for biowaste management. J. Clean. Prod. 2013, 47, 70-76. [CrossRef]

61. Alparslan, A.Y.; Karacali, U.C.A.; Kilinc, N. Composting as a Waste Management Method. Int. Environ. Appl. Sci. 2017, 12, 244-255.

62. Luo, W.; Ji, Y.; Qu, L.; Dang, Z.; Xie, Y.; Yang, C.; Tao, X.; Zhou, J.; Lu, G. Effects of eggshell addition on calcium-deficient acid soils contaminated with heavy metals. Front. Environ. Sci. Eng. 2018, 12, 4. [CrossRef]

63. Sudharsan, V.V.; Kalamdhad, A.S. Efficiency of Rotary Drum Composting for Stabilizing Vegetable Waste during Pre-Composting and Vermicomposting. Environ. Process. 2016, 3, 829-841.

64. Domínguez, J.; Martínez, C.H.; Álvarez, C.M.; Lores, M. Vermicomposting grape marc yields high quality organic biofertiliser and bioactive polyphenols. Waste Manag. Res. 2014, 32, 1235-1240. [CrossRef]

65. Yadav, A.; Gard, V.K. Industrial wastes and sludges management by vermicomposting. Rev. Environ. Sci. Bio/Technol. 2011, 10, 243-276. [CrossRef]

66. Devi, C.; Khwairakpam, M. Bioconversion of Lantana camara by vermicomposting with two different earthworm species in monoculture. Bioresour. Technol. 2020, 296, 122308. [CrossRef]

67. Ansari, A.; Hanief, A. Microbial degradation of organic waste through vermicomposting. Int. J. Sustain. Agric. Res. 2015, 2, 45-54. [CrossRef]

68. Che., J.; Lin, W.; Liao, H.; Yu, Z.; Lin, H.; Zhou, S. Insights into compositional changes of dissolved organic matter during a full-scale vermicomposting of cow dung by combined spectroscopic and electrochemical techniques. Bioresour. Technol. 2020, 301, 122757. [CrossRef] [PubMed]

69. Kumar, A.; Gupta, R.K.; Kumar, S. Variation in organic carbon content and carbon nitrogen ratio in vermicompost as affected by substrate Straw. Forage Res. 2017, 43, 46-49.

70. Nahrul, H.Z.; Abdul, K.H.P.S.; Jawaid, M.; Hakimi, I.M.; Astimar, A.A. Exploring chemical analysis of vermicompost of various oil palm fibre waste. Enviromentalist 2010, 30, 273-278. [CrossRef]

71. Lakshmi, P.M.; Nagalakshmi, N.; Shanmuga, P.M. Analysis of nutrient contents in vermicompost. Eur. J. Mol. Biol. Biochem. 2015, 2, 42-48.

72. Othman, N.; Irwan, J.M.; Roslan, M.A. Vermicomposting of food waste. Int. J. Integr. Eng. 2012, 4, 39-48.

73. Akbar, B.A.; Goudarzi, G.; Neisi, A.; Ebrahimi, Z.; Alavi, N. Vermicomposting of cow dung, kitchen waste and sewage sludge with bagasse using Eisenia fetida. J. Adv. Environ. Health Res. 2016, 4, 88-94. 
74. Ravindran, B.; Mnkeni, P.N.S. Bio-optimization of the carbon-to-nitrogen ratio for efficient vermicomposting of chicken manure and wastepaper using Eisenia fetida. Environ. Sci. Pollut. Res. 2016, 23, 16965-16976. [CrossRef] [PubMed]

75. USDA. Carbon to Nitrogen Ratios in Cropping Systems. United States Department of Agriculture. Natural Resources Conservation Service. 2011. Available online: https://www.nrcs.usda.gov/Internet/ FSE_DOCUMENTS/nrcseprd331820.pdf (accessed on 27 August 2020).

(c) (C) 2020 by the authors. Licensee MDPI, Basel, Switzerland. This article is an open access article distributed under the terms and conditions of the Creative Commons Attribution (CC BY) license (http://creativecommons.org/licenses/by/4.0/). 